\title{
Budget support as a tool for innovative and technological development of agriculture in Russia
}

\author{
Oleg Kholodov ${ }^{1}$, Lyudmila Usenko $^{1}$, and Marina Kholodova ${ }^{1,2, *}$ \\ ${ }^{1}$ Rostov State University of Economics, Bolshaya Sadovaya str. 69, Rostov-on-Don, 344002, Russia \\ ${ }^{2}$ Federal Rostov Agricultural Research Centre (FSBSI FRARC), Institutskaya str. 1, p. Rassvet, \\ Aksay district, Rostov region, 346735, Russia
}

\begin{abstract}
The article is devoted to budget support as the main tool of innovative and technological development of agriculture in Russia within the framework of the State Program. Special attention is paid to the mechanism of subsidizing preferential investment loans aimed at modernizing the material and technical base of agricultural production. The assessment of the state of material and technical support of agricultural production in Russia in comparison with other countries of the world is given. The composition and structure of the limits of the resource provision of the departmental project "Stimulating investment activity in the agroindustrial complex" for 2017-2019 is analyzed. Special attention is paid to the mechanism of preferential investment lending. The dynamics of the purchase of agricultural machinery in the Russian Federation is presented, taking into account the new mechanism of state support that encourages the technical re-equipment of the industry. The rating of the leading credit and financial organizations of Russia participating in the implementation of the mechanism of preferential investment lending is presented. The composition and structure of concessional investment loans have been studied. The article describes the practice of updating the material and technical base of agriculture through Resolution No. 1432 and the system of JSC "Rosagroleasing".
\end{abstract}

\section{Introduction}

In the mechanism of modern structural transformations associated with the breakthrough scientific and technological and socio-economic development of Russia, a special role is assigned to the domestic agricultural sector of the economy, which ensures the national security of the state in the face of global challenges and threats [1]. The current geopolitical picture of the world requires Russia to create conditions to ensure the innovative and technological development of agricultural production, without which the strategy of advanced development of the national economy will not be achieved.

Practice shows that for the formation of a new technological order in agriculture, based on the development of promising innovative world-class technologies, a powerful impulse

\footnotetext{
* Corresponding author:kholodovama@rambler.ru
} 
is needed to update the material and technical park, which can concentrate financial resources in the priority areas of modernization and development of its industries. The key tool for achieving these goals is the formation of an effective mechanism for stimulating investment activity in the agricultural sector on the principles of preferential lending to agricultural producers. As a result, the issues of effective state support for agricultural production, contributing to its transition to innovative rails, are of particular importance [2].

Despite government measures to stimulate the processes of modernization of machinetractor Park in agriculture, among which: contribution from 15,0 up to $20 \%$ of the costs to agricultural producers for the purchase of agricultural machinery, upgrading of machine and tractor fleet of agricultural production of JSC "Rosagroleasing", did not significantly affect the state of the material-technical base of agriculture.

\section{Research Result}

Studies have shown that over the past five years, the availability of agricultural machinery in Russia has lagged significantly behind many countries of the world, especially the European Union and the United States (Fig. 1). This negative situation is caused by a high degree of deterioration of the material and technical base. In 2017, the number of domestic agricultural producers of tractors with a service life of more than 10 years was $59.7 \%$, grain harvesters- $45.0 \%$, forage harvesters- $43.6 \%$, despite the weak and unstable dynamics of improving the age structure of the park.

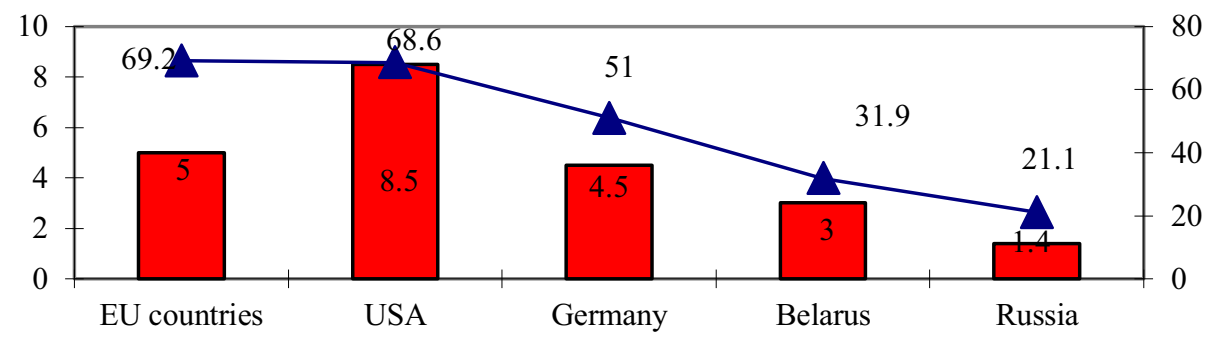

Energy capacity, hp/ha $\longrightarrow$ - Yield, hundredweight / ha

Fig. 1. Energy supply and grain yield in Russia and other countries (on average for 5 years) [1].

The satisfaction of agricultural producers with the demand for tractors in 2017 was 80.6 $\%$, for grain harvesters- $79.2 \%$, for forage harvesters- $77.9 \%$.

It is no secret that around 30-40\% of grain crops in most of the regions removed hired equipment, distilled from the southern regions, on the one hand, significantly facilitates harvesting companies in the small forms of management and decreases the cost of production the value of investments in technical equipment industry, on the other - brakes technical and technological modernization of agriculture, does not stimulate the process of expanded reproduction in agriculture and reduce the effectiveness of its development $[3,4]$.

In the current conditions, the search for the most effective areas of state support for the modernization of the material and technical base of agricultural production industries on an innovative basis is becoming more urgent by replacing obsolete and physically worn-out equipment with modern machines with high reliability, productivity, fuel efficiency, ergonomic and environmental characteristics, and bridging the gap between the need for equipment and its availability in agricultural producers. 
In this regard, since 2017, Russia has introduced a new mechanism for preferential lending in the agro-industrial complex by the Decree of the Government of the Russian Federation of December 29. 2016. no. 1528, aimed at stimulating the demand of consumers of agricultural machinery on the basis of providing subsidies from the federal budget to Russian credit organizations to compensate for the lost income on loans issued to agricultural producers, organizations and individual entrepreneurs engaged in the production, primary and (or) subsequent (industrial) processing of agricultural products and their sale, at a preferential rate.

According to the Resolution, the cost of credit resources for the final borrower for the purchase of equipment is not more than $5.0 \%$ per annum. The state pays compensation to credit institutions for the lost income from lending to farmers. The amount of the subsidy to commercial banks is $100 \%$ of the key rate of the Bank of Russia.

It should be noted that in countries where the main world producers of agricultural machinery, the key rate of the Central banks in times lower than in Russia: in the United States $-1.5 \%$, Canada - up to $1.25 \%$ EU $0 \%$, in Japan or minus $0.1 \%$, in Sweden - minus $0.5 \%$.

According to estimates of Ministry of agriculture-a new mechanism of state support will increase the demand for agricultural machinery of domestic production, advanced load capacity of factories, to organize more jobs, improve access to credit for farmers, reduce their financial burden, periodentium earlier abstract working capital to pay subsidized the interest rate for financing of current production and economic activity, which is an essential tool for the villagers.

Studies have shown that in the structure of the resource support of the departmental project "Stimulating investment activity in the agro-industrial complex" under the State Program, the share of state expenditures on concessional lending to organizations increased from $11.0 \%$ in 2017 to $60.8 \%$ in 2019 (fig. 2).

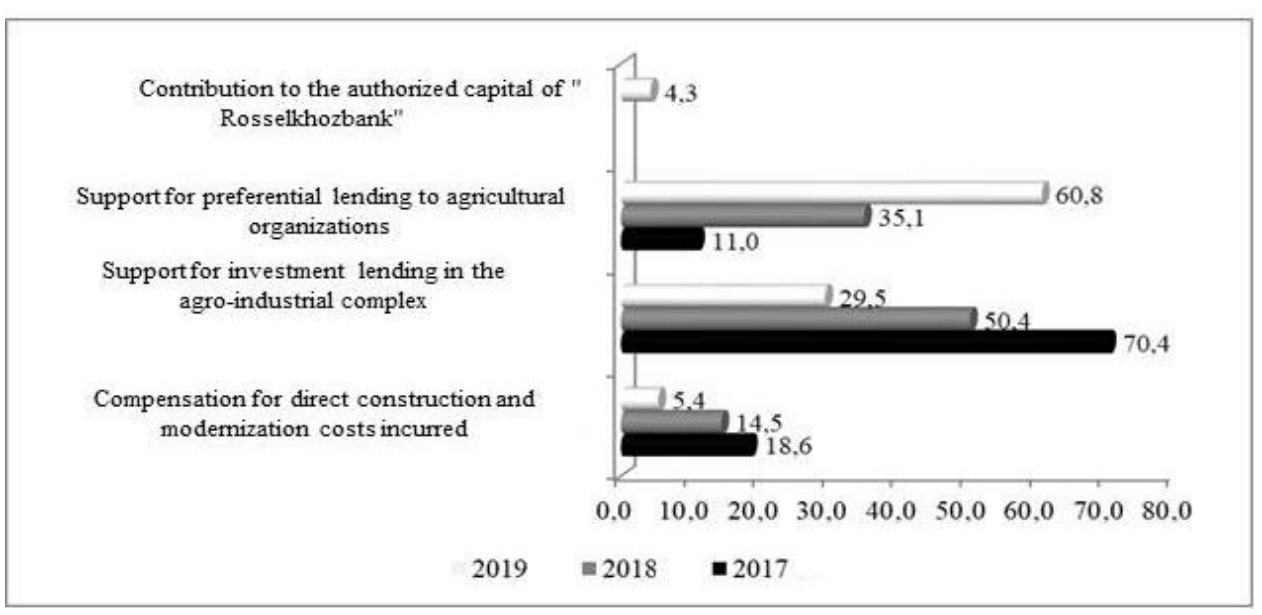

Fig. 2. Dynamics of the resource provision of the departmental project "Stimulating investment activity in the agro-industrial complex" of Russia for 2017-2019, billions of rubles [5].

The study revealed that in the short period of implementation of the program of preferential crediting APK significantly changed the amounts of funding from 9104.6 million RUB in 2017 to 66 of 174.3 million RUB in 2019 (7.3-fold) and structure directions. Thus, the largest share in the structure of short-term soft loans intended for the purchase of fuels and lubricants, plant and animal protection products, mineral fertilizers and other current assets accounts for the financing of innovative and technological 
development of the export-oriented crop production industry in 2019-59.7\% (against $30.0 \%$ in 2017) (Fig. 3).

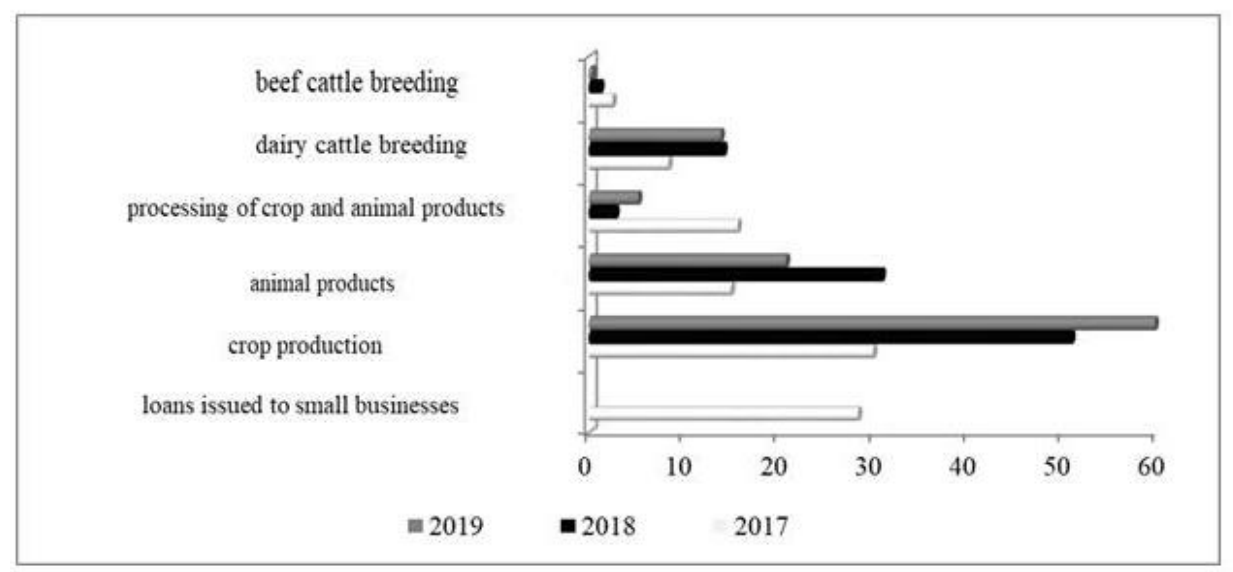

Fig. 3. Composition and structure of the program of preferential short-term lending to the agroindustrial complex for 2017-2019, \% [5].

The next no less significant items of concessional short-term lending were the development of the domestic livestock and dairy cattle industry, the share of which in 2019 was $20.8 \%$ and $13.9 \%$, respectively. The volume of concessional short-term lending to small businesses has been transformed within the framework of the industry focus of activity $[5,6,7]$.

The course of breakthrough scientific and technological development of the agricultural sector of the national economy contributed to the transformation of the structure of preferential investment lending in priority areas of development of agricultural production, including its innovative and technological component. The main idea of preferential investment lending is to modernize the machine and tractor fleet of the crop production industry, mechanize livestock complexes, and increase processing capacities. The development of processing makes it possible to ensure guaranteed sales to agricultural producers, create additional jobs, including in rural areas, and also creates prerequisites for the reorientation of food exports from raw materials to finished products. The priority direction of financing the program of preferential investment lending in 2019 was the modernization of the machine and tractor fleet. Thus, in the structure of concessional investment loans, a significant share of budget support funds exceeded $40.0 \%$ in 2019. (or 43.6 billion rubles) was allocated for the purchase of modern reproductive wide-range agricultural machinery of domestic production, which is not inferior to world analogues.

An equally important issue was the renewal of material and technical support for such strategically important agricultural sectors as crop production, animal husbandry and processing of crop and livestock products, which accounted for $33.9 \%$ of the total volume of investment lending (Fig. 4). 

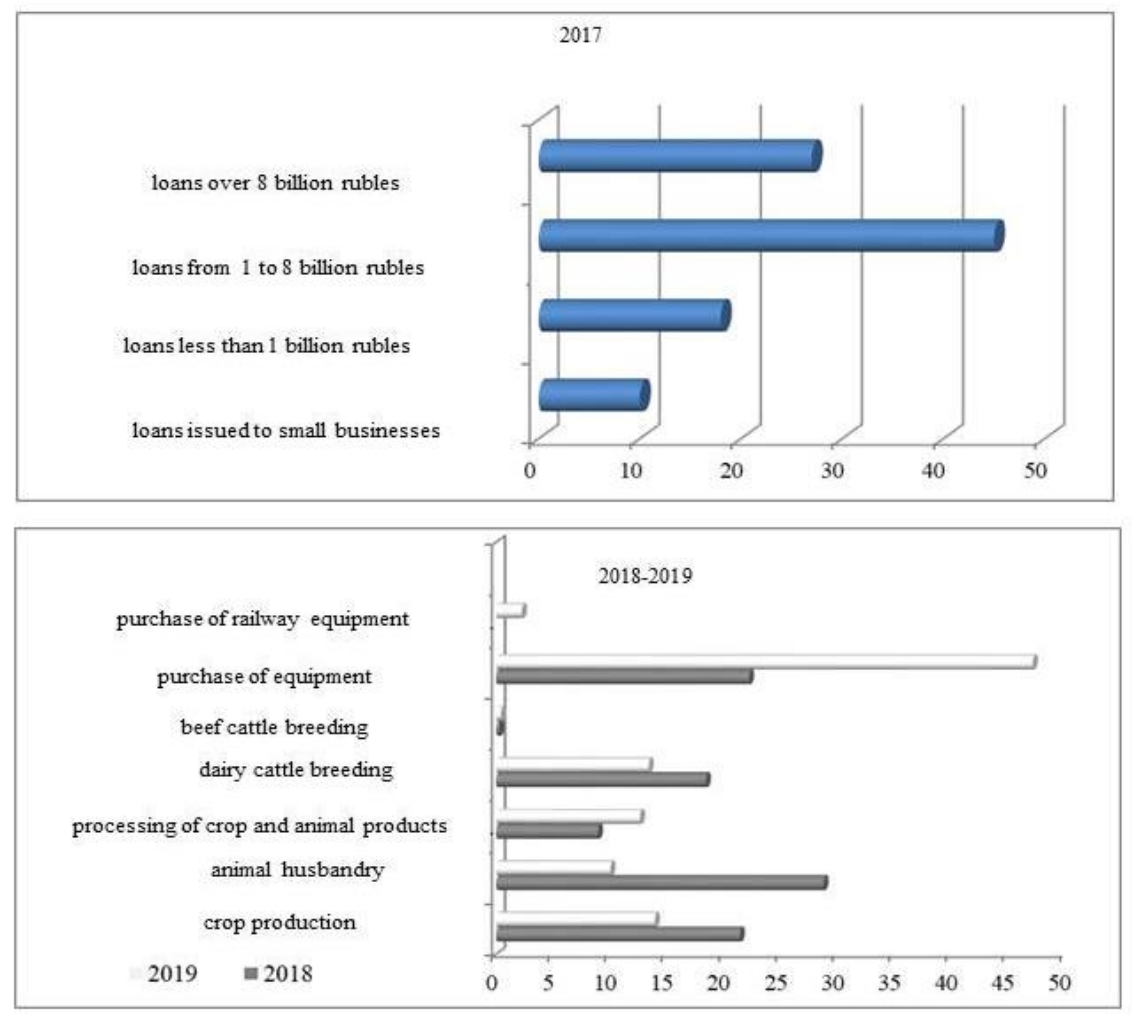

Fig. 4. Composition and structure of preferential investment lending to the agroindustrial Complex of the Russian Federation for 2017-2019, \% [5].

It should be noted that the most acute economic problem of domestic animal husbandry remains the low competitiveness of products, due to the high cost of working time, energy, low productivity and reproduction of the herd, the insufficient level of material and technical equipment of farms and the use of resource-saving technologies. The share of investment loans aimed at the mechanization of the dairy cattle industry in 2019 amounted to $12.4 \%$ of the total financing of the program.

Such credit institutions as PJSC Sberbank, JSC "Rosselkhozbank" and others take an active part in preferential investment lending (Fig.5).

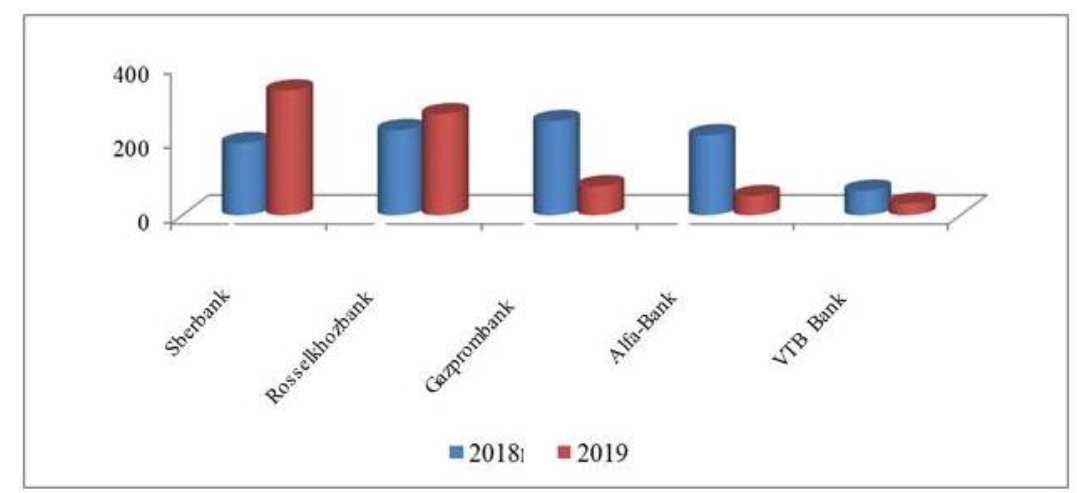

Fig. 5. Dynamics of the volume of financing of concessional investment loans by leading credit institutions in Russia for 2018-2019 [5]. 
An equally important area of state support for the innovative and technological development of agricultural sectors within the framework of the Departmental Project "Stimulating investment activity in the agro-industrial complex" is the financing of investment loans in the agro-industrial complex of Russia, the lion's share of which in 2019. it accounted for early-maturing livestock industries, including pig and poultry farming, technical and technological modernization of the machine and tractor fleet, vegetable growing of closed ground with a year-round production cycle- $22,7 \%, 16,2 \%, 15,4 \%$, $11,1 \%$ accordingly.

Undoubtedly, a significant increase in budget funds for financing concessional investment loans across the country is a positive trend, but the allocated resources are not enough to replace a significant share of the worn-out machine and tractor fleet of the domestic agro-industrial complex $[5,8,9]$.

Thus, the difficult macroeconomic situation in the country in the period 2017-2019, due to the fall in the national currency, the depreciation of agricultural producers ' incomes, in the context of easier access to investment loans, negatively affected the amount of effective demand for agricultural machinery of domestic and foreign production. In particular, there is a decrease in demand in such a large segment as tractors and combines. Total sales of tractors in Russia in 2019 amounted to 10.7 thousand units of tractors against 11.0 thousand units in 2017, 4.6 thousand units. grain harvesters (in 2017-6.2 thousand units), 0.6 thousand units of forage harvesters (in 2017-0.7 thousand units). The preference of the villagers is given to domestic mechanical engineering, which is almost as good as its world counterparts, and has a more attractive price. Moreover, the service, warranty and postwarranty service of agricultural machinery by Russian manufacturers is more affordable and timely.

At the same time, access to credit has a limited range of highly profitable enterprises, which increases the socio-economic differentiation of regions, forming groups of depressed territories. Thus, in 2019, the largest share of concessional short-term loans (35.3\%) fell on the Central Federal District, 20.8\% - on the Volga Federal District, $15.8 \%$ - on the Southern Federal District, $10.7 \%$ - on the Siberian Federal District, $5.1 \%$ - on the NorthWestern District, $4.0 \%$ - on the Far Eastern District, $5.2 \%$ - on the North Caucasus, $3.3 \%$ - on the Ural Federal District $[1,10,11]$.

In order to stimulate the demand for modern high-performance agricultural machinery of domestic production and investment activity in the agricultural machinery industry at the state level, the decree of the Government of the Russian Federation No. 1432 of 27.12.2012 was developed. In accordance with the Resolution, the federal budget provides for the provision of subsidies to agricultural machinery manufacturers to compensate for lost income in connection with its sale to agricultural producers at a discount of 25.0-30.0\%. The implemented mechanism of state support has become a serious tool that motivates agricultural producers to modernize the level of technical equipment of the machine and tractor fleet. Thus, according to the Ministry of Agriculture of the Russian Federation, the total amount of subsidies for this equipment in 2018 amounted to 10.0 billion rubles, the number of subsidized equipment reached 17,842 units. (Fig. 6).

It should be noted that the acceleration of the pace of modernization of the machine and tractor fleet of Russian agricultural industries is largely due to the implementation of Rosagroleasing programs, which in recent years have become a significant alternative to traditional banking products. The most popular program among the clients of JSC "Rosagroleasing" is the Renewal Program of the agricultural machinery Fleet (OPT), the conditions of which have no analogues in the market. Farmers are provided with new modern equipment without advance payment with a deferred first payment for 6 months at a preferential rate of $3.0 \%$ per annum $[12,13,14]$. 


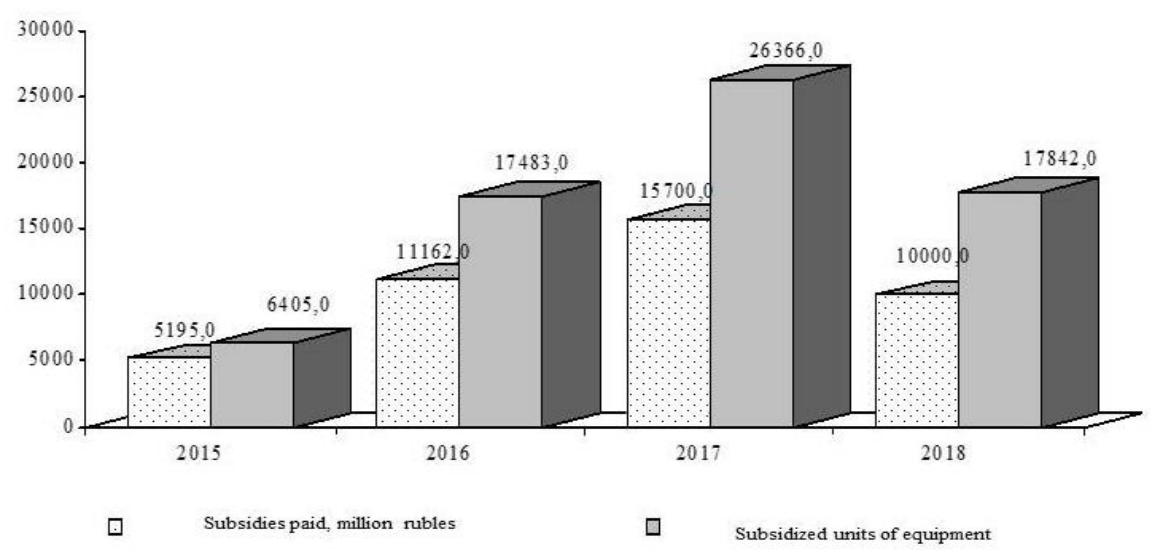

Fig. 6. Dynamics of subsidies to agricultural machinery manufacturers in 2015-2018 [5].

So, in the framework of the Program of updating of Park of agricultural machinery through JSC "Rosagroleasing" for the 2017-2019 biennium. in agriculture was delivered machinery on conditions of preferential leasing in the amount of 54 million RUB 472, in particular, 3043 tractors, harvesters 2 993, 2574 vehicles and more than 7774 units other equipment (Fig. 7).

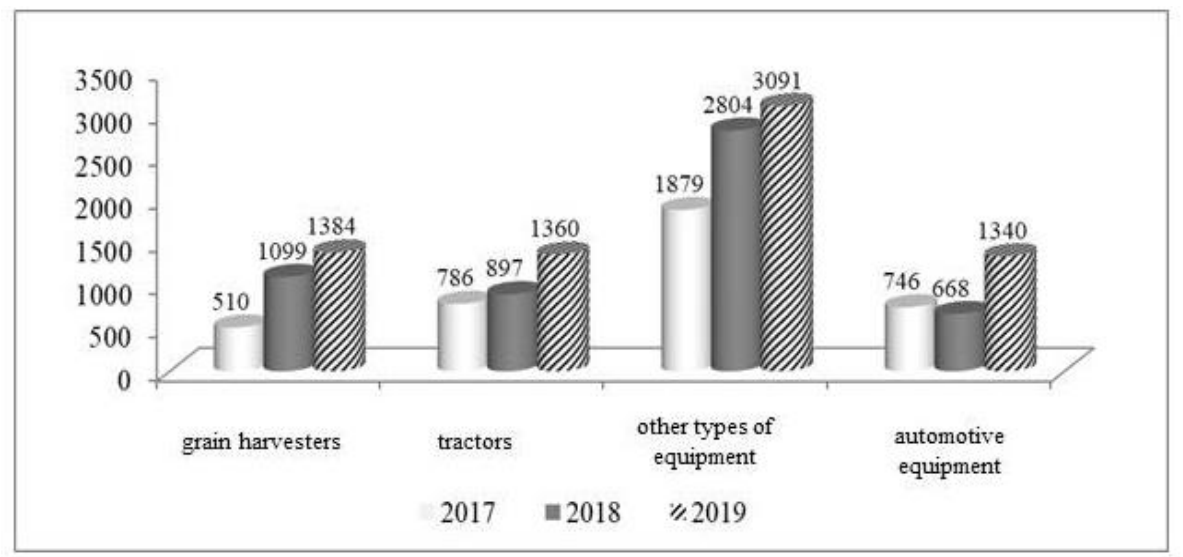

Fig. 7. Dynamics of delivery of agricultural and automotive equipment by «Rosagroleasing» JSC to agricultural producers of Russia on the terms of financial lease (leasing) for 2017-2019 [5].

\section{Conclusion}

Summing up, it should be noted the key role of financial and economic support for innovative and technological development in increasing the competitiveness of the agricultural sector in the context of the implementation of the export-oriented strategy. Currently, not all regions of the country pay sufficient attention to the problem of modernization of the machine and tractor fleet. The modernization process is often spontaneous and only partially meets the needs of rural producers. A key role in stimulating innovation and technological development of agricultural production is state support of agriculture, which allows not only to systematically update the material and technical base of agricultural production and increase the competitive potential of the industry $[1,15,16]$. 
However, for a large-scale modernization of the material and technical base of the domestic agro-industrial complex in the long term, it is necessary to develop a strategy for the technical and technological modernization of agricultural production. The basis for the implementation of the strategy should be medium-term state programs that reflect the conditions of technical and technological re-equipment of the industry, targets for the formation of an optimal qualitative and quantitative composition of the machine and tractor fleet.

\section{References}

1. A.N. Tarasov, M.A. Kholodova, The economy of agricultural and processing enterprises 8, 38-43 (2018)

2. O.A. Kholodov, M.A. Kholodova, Bulletin of the Don State Agrarian University 4(30), 129-137 (2018)

3. S.K. Wegren, Journal of Eurasian Studies 3(2), 193-202 (2012) doi: 10.1016/j.euras.2012.03.010

4. M.Y. Anokhina, A.V. Golubev, O.N. Kondrashina, Journal of Environmental Management and Tourism 1(33), 119-134 (2019) doi: 10.14505/jemt.v10.1(33).12

5. Web Portal of Federal state statistics service, http: www.gks.ru

6. M.A. Kholodova, S.G. Safonova, M.S. Sheikhova, Regional problems of economic transformation 11(109), 42-50 (2019) doi: 10.26726/1812-7096-2019-11-42-50

7. O.A. Kholodov, Vector of Science of Tolyatti State University. Series: Economics and Management 4, 55-61 (2019) doi: 10.18323/2221-5689-2019-4-55-61

8. V. Uzun, N. Shagaida, Z. Lerman, Land Use Policy 83, 475-487 (2019) doi: /10.1016/j.landusepol.2019.02.018

9. L.N. Usenko, Y.G. Chernysheva, V.A. Guzey, O.M. Todorova, A.M. Usenko, International journal of trade and global markets 2-3, 160-167 (2017) doi: 10.1504/ijtgm.2017.086074

10. M. Slozhenkina, I. Gorlov, M. Kholodova, O. Kholodov, O. Shakhbazova, D. Mosolova, AGRITECH-III-2020 IOP Publishing IOP Conf. Series: Earth and Environmental Science 548 (2020) doi:10.1088/1755-1315/548/8/082037

11. O. Isaeva, M. Kabanenko, A. Chistyakov, L. Dubrova, N. Filin, E3s Web of Conferences 175, 13004 (2020) doi: 10.1051/e3sconf/202017513022

12. M. Kholodova, M. Kabanenko, L. Orekhova, L. Dubrova, Z. Kolycheva, E3s Web of Conferences 175, 13004 (2020) doi:10.1051/e3sconf/202017513004

13. R.F. Gataullin, A.A. Askarov, G.N. Khuzhakhmetova, N.V. Yarkov, Economic Region 2, 271-284 (2015) doi 10.17059/2015-2-22

14. I. Boldyreva, O. Andryushchenko, A. Nikitaeva, Z. Udalova, J. Rudash, Journal of environmental management and tourism 8.4(20), 642-647 (2017) doi:10.14505/ jemt.v8.3(19). 15

15. N.D. Avarsky, A.V. Altapov, T.M. Kuznetsova, Economics of agricultural and processing enterprises 1, 22-31 (2017)

16. V. Surovtsev, E. Payurova, Agribusiness: economics and Management 1, 70-76 (2017) 